\section{Discussion}

The most frequently reported interstitial deletion of $2 \mathrm{q}$ involves the segments $\operatorname{del}(2)(\mathrm{q} 31 \mathrm{q} 33)$ and the clinical features of the other eight reported cases are outlined in the table. It is apparent that in addition to the general features shared with other $2 \mathrm{q}$ deletions (mental retardation, microcephaly, growth failure, and congenital heart defects),${ }^{1-3}$ more specific features of $\operatorname{del}(2)$ (q31q33) deletions, as suggested by Schinzel, ${ }^{9}$ include microphthalmia, corneal anomalies, ptosis, a beaked nose, micrognathia, cleft palate, large or low set ears, clinodactyly of the fifth finger, camptodactyly of the fingers, and syndactyly of the toes.

The present case shares some of the features of this subgroup of $2 \mathrm{q}$ deletions but he also shows distinctive skin pigmentation. The distribution of the skin abnormality did not follow Blaschko's lines and we found no evidence of chromosomal mosaicism by demonstrating the identical karyotypes in the fibroblasts derived from the pigmented and nonpigmented skin. The skin pigmentation may be related to the breakpoints of this deletion allowing expression of an otherwise suppressed gene, or it may represent a coincidental abnormality; further assignment of gene loci to $2 \mathrm{q} 31-\mathrm{q} 33$ may resolve this question.

The structural gene for the soluble form of isocitrate dehydrogenase (ICD-S, E.C.1.42) has been previously mapped to $2 \mathrm{q} 33.3$ by somatic cell hybridisation and gene dosage studies. ${ }^{10}$ The presence of normal levels of ICD-S in the proband suggested that the deletion breakpoint in band $\mathrm{q} 33 \overrightarrow{\mathrm{m}}$ lies proximal to the ICD-S locus.

\section{References}

${ }^{1}$ Lucas J, Faivre J, Le Mee F, Hubert S, Pluquailec K, Picard F De novo interstitial deletion: 46,XX,del(2)(q14q21) and premature craniosynostosis. Ann Genet (Paris) 1987;30:33-8.

2 Benson K, Gordon M, Wassman ER, Chung T. Interstitial deletion of the long arm of chromosome 2 in a malformed infan $P$ with karyotype 46,XX, del(2)(q31q33). Am J Med Genet 1986;25:405-11.

3 Young RS, Shapiro SD, Hansen KL, Hine LK, Rainosek DR? Guerra FA. Deletion 2q: two new cases with karyotypes 46,XY,del(2)(q31q33) and 46,XX,del(2)(q36). J Med Gene? 1983;20:199-202.

4 Buchanan PD, Rhodes RL, Stevenson CE. Interstitial deletion 2q31 $\rightarrow \mathrm{q} 33$. Am J Med Genet 1983;15:121-6.

5 Al-Awadi SA, Farag TI, Naguib $\mathrm{K}$, et al. Interstitial deletion of the long arm of chromosome 2: $\operatorname{del}(2)(\mathrm{q} 31 \mathrm{q} 33)$. J Med Geneb 1983;20:464-5.

6 Franceschini P, Silengo MC, Davi G, Bianco R, Biagoli M.Interstitial deletion of the long arm of chromosome 2 (q31q33) in a girl with multiple anomalies and mental retardation. Hum Genet 1983;64:98.

7 Taysi K, Dengler DR, Jones LA, Heersma JR. Interstitia deletion of the long arm of chromosome 2: case report ank review of the literature. Ann Genet (Paris) 1981;24:245-7.

8 Pai GS, Rogers JF, Sommer A. Identical multiple congenitabo anomalies/mental retardation (MCA/MR) syndrome due to $\operatorname{del}(2)(\mathrm{q} 32)$ in two sisters with intrachromosomal insertional translocation in their father. Am J Med Genet 1983;14:189-95.

9 Schinzel A. Catalogue of unbalanced chromosome aberrations in man. Berlin: Walter de Gruyter, 1984:117.

10 Narahara K, Kimura S, Kikkawa K, et al. Probable assignmen of soluble isocitrate dehydrogenase (IDH1) to 2q33.3. HumD Genet 1985;71:37-40.

Correspondence and requests for reprints to Dr I A $\overline{\vec{\rho}}$ Glass, Duncan Guthrie Institute of Medica? Genetics, Yorkhill, Glasgow G3 8SJ.

\title{
A terminal deletion (14)(q31.1) in a child with microcephaly, narrow palate, gingival hypertrophy, protuberant ears, and mild mental retardation
}

\author{
FU-SUN YEN, PHILIP E PODRUCH, AND BERNARD WEISSKOPF \\ Child Evaluation Center, Department of Pediatrics, University of Louisville School of Medicine, Louisville, \\ Kentucky, USA.
}

SUMMARY A female child with a terminal deletion on the long arm of chromosome 14, $46, \mathrm{XX}, \operatorname{del}(14)(\mathrm{q} 31.1)$, presented with microcephaly, narrow palate, gingival hypertrophy, protuberant ears, and a small haemangioma on the back. She was mildly mentally retarded. Only a few patients with a partial

Received for publication 14 March 1988.

Revised version accepted for publication 8 June 1988 deletion of $14 q(14 q-)$ have been reported without consistent clinical findings. Although aO clinical syndrome associated with ring chromo-o some 14, r(14), has been established, no distinct pattern has been so far reported in ${ }^{+}$ $14 \mathrm{q}-$.

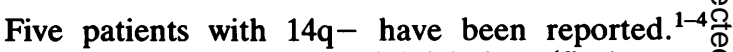
Three patients had interstitial deletions (fig 1, cases $\varrho$ 1,2 , and 3 ). One patient had a terminal deletion (fig? 
1, case 4). The remaining patient had a chromosome mosaicism with two cell lines, one with a $46, \mathrm{XX}$ karyotype. The other cell line had a complex inversion and a terminal deletion (fig 1, case 5). Patients with a similar phenotypic pattern associated with r(14) have been observed, establishing a clinical entity. ${ }^{5}$

We wish to report a patient with a terminal deletion (14)(q31.1) (fig 1, case 6). The patients with $14 q-$ have so far not presented with similar clinical features. ${ }^{1-4}$ Whether or not this is because of the deletion of different chromosome segments of $14 \mathrm{q}$ is not known (fig 1). Reported features vary and are noted in the table.

\section{Case report}

The proband (fig 2) was born on 17.4.79 and was seen in the Child Evaluation Center at five years three months and again at seven years four months

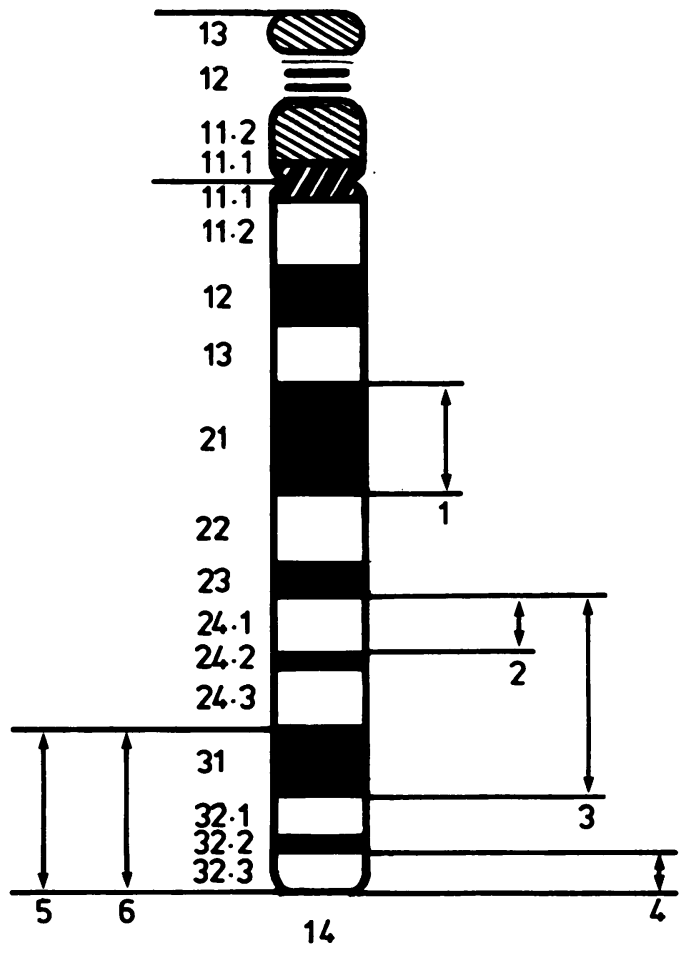

FIG 1 Schematic representation of deleted chromosome segments of $14 q$ in six patients. Case 1: del(14) $(q 13 q 22) .^{1}$ Case 2: $\operatorname{del}(14)(q 23 q 24.2) .{ }^{2}$ Case 3: $\operatorname{del}(14)(q 23 q 32) .{ }^{2}$ Case 4: $\operatorname{del}(14)(q 32.3){ }^{3}$ Case 5: $\operatorname{mos} 46, X X / 46, X X$, inv(14) $(q 21 q 31), \operatorname{del}(14)(q 31)=46 \%: 54 \% .{ }^{4}$ Case $6: \operatorname{del}(14)$ (q31.1), present case.

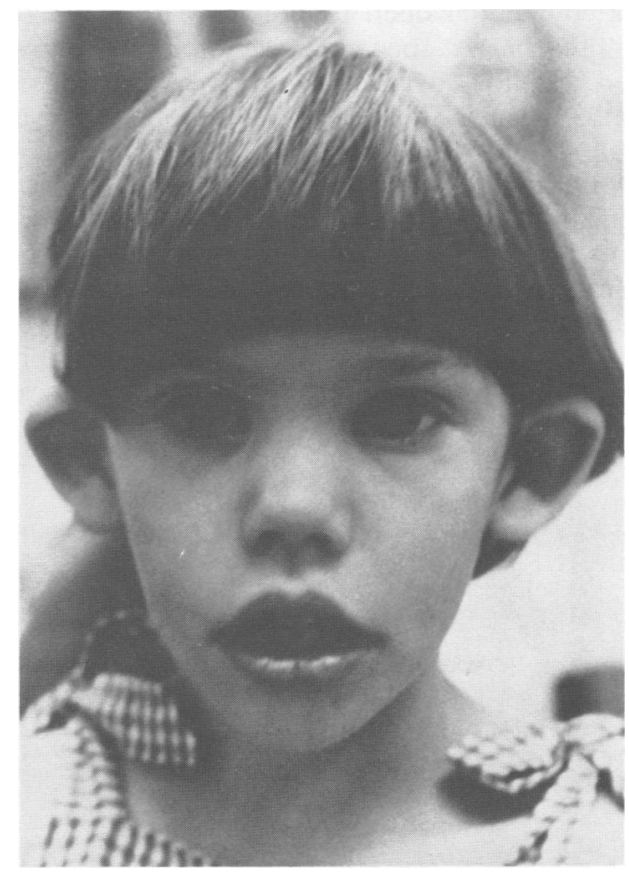

FIG 2 The proband.

of age. She was the younger of two living children. At the time of her birth, her father and mother were 32 and 29 years of age, respectively. The pregnancy, apart from excessive weight gain, and the delivery were uncomplicated. Birth weight was $4400 \mathrm{~g}$, length was $52 \mathrm{~cm}$, and head circumference was $34 \cdot 3$ $\mathrm{cm}$ (50th centile). She was noted to have a fractured right clavicle at birth. Her motor milestones were reported to be in the normal range. She used words at nine months of age, but sentences were not present until four years of age. She was reported to have had one febrile convulsion at 18 months. The EEG was normal.

Physical examination at seven years four months of age showed she was at the 40th centile for height $(120 \mathrm{~cm})$ and the 25 th centile for weight $(20 \mathrm{~kg})$. Her head circumference of $46.2 \mathrm{~cm}$ was below the 2nd centile. She was a thin, slightly apprehensive, Caucasian female. Physical findings included microcephaly, protuberant ears, epicanthic folds, perforated left tympanic membrane, micrognathia, pointed chin, tight tongue frenulum, narrowed palate, gingival hypertrophy, open bite, and blue sclerae. She was myopic. A faded haemangioma was present on her back. Neurological examination indicated poor tongue control, with otherwise normal cranial nerves. There was incoordination with 
brisk, but equal deep tendon reflexes. Hypotonia was present. A speech articulation problem was noted. Scoliosis was reported at seven years two months of age. The sensory, autonomic, and cerebellar systems were normal.

Dermatoglyphic studies were unremarkable. The urine amino acid screening chromatogram showed a normal pattern. The tests for reducing substances and mucopolysaccharides were normal. Skull $x$ rays indicated that the calvarium was small compared to the size of the face, consistent with microcephaly. No abnormal findings were noted on the CT scan of the brain.
Psychological studies obtained when she was five $\overrightarrow{\vec{*}}$ years three months of age indicated an IQ of 68 ono the Stanford-Binet Intelligence Scale and an IQ of 84 on the Leiter International Scale. When she was $\overline{\bar{n}}$ seven years four months, psychological testing using $\mathbb{\Phi}$ the Stanford-Binet test indicated an IQ of 64. When measured by the WISC-R, a verbal IQ of 52 , a perfor- $\infty$ mance IQ of 57 , and a full scale IQ of 50 was obtained. $\vec{\circ}$ Her receptive and expressive language skills were $\overrightarrow{ }$ depressed and relatively lower than the IQ scores. $A_{\sigma}^{\omega}$ mild speech articulation problem was noted.

Chromosome studies indicated that the child hado a 46,XX,del(14)(q31.1) karyotype by GTG banding
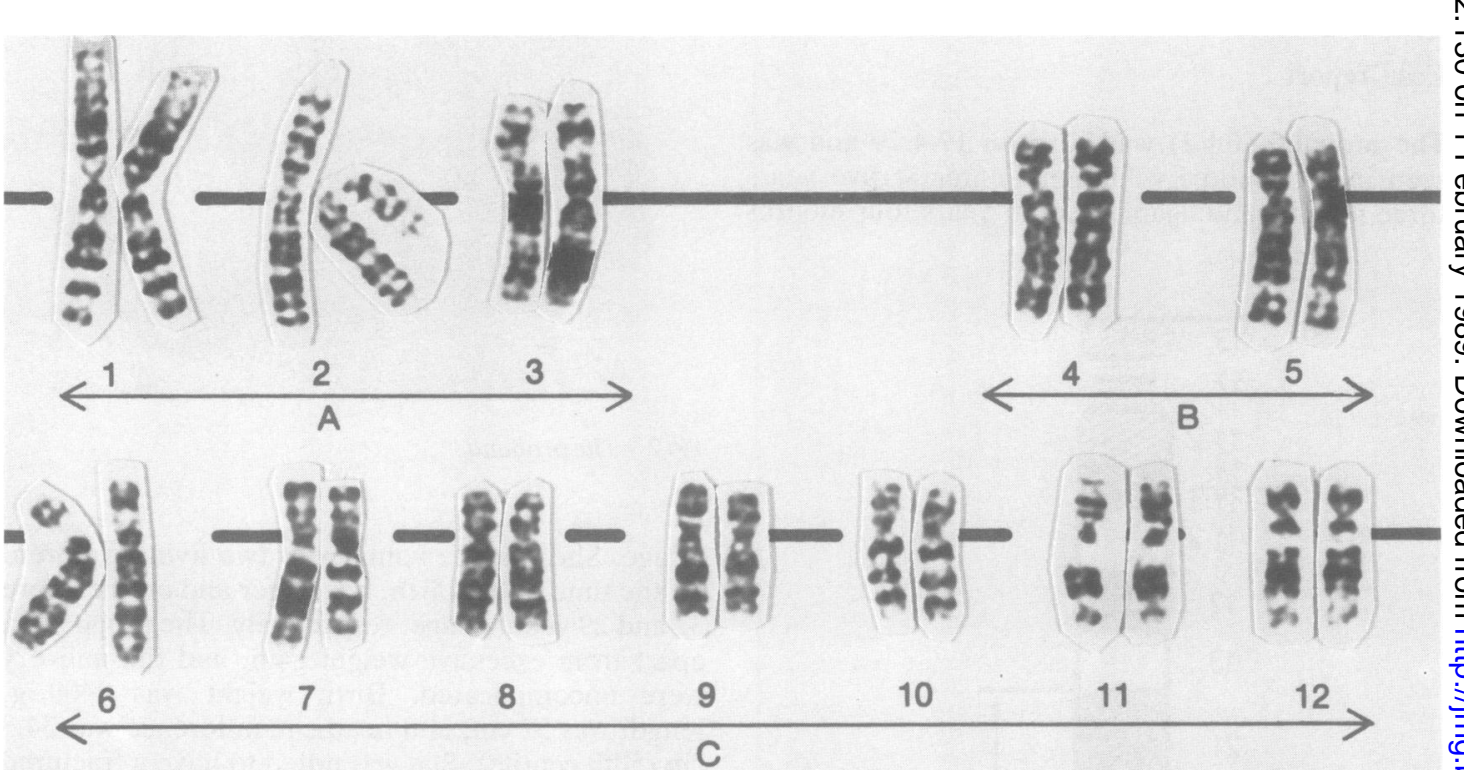

C
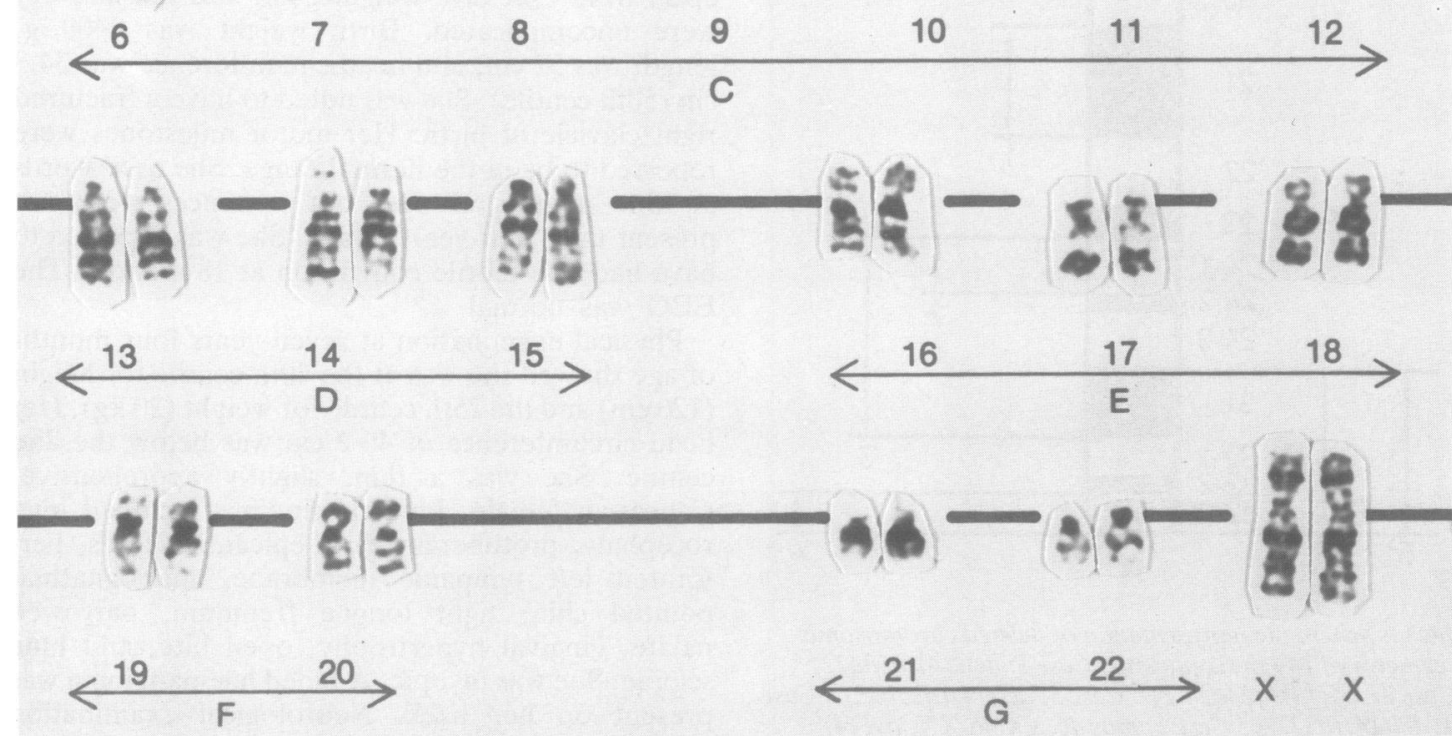

FIG 3 GTG banded karyotype of the proband, 46,XX, del(14)(q31.1). 
TABLE Comparison of clinical features in the proband with those with $14 q-$ or $r(14)$ in published reports.

\begin{tabular}{|c|c|c|c|c|c|c|c|}
\hline \multirow[t]{3}{*}{ Dysmorphic features } & \multicolumn{6}{|c|}{ Features in $14 q-$} & \multirow{3}{*}{$\begin{array}{l}\text { Features } \\
\text { in } r(14)\end{array}$} \\
\hline & \multicolumn{6}{|c|}{ Case } & \\
\hline & 1 & 2 & 3 & 4 & 5 & 6 & \\
\hline \multicolumn{8}{|l|}{ Head } \\
\hline Dolichocephaly & & & + & & & & + \\
\hline Microcephaly & & & & & & + & + \\
\hline High forehead & & & & + & & & + \\
\hline Short neck & & & & & + & & + \\
\hline \multicolumn{8}{|l|}{ Eyes } \\
\hline $\begin{array}{l}\text { Small palpebral fissures } \\
\text { Ptosis }\end{array}$ & & & + & & & & + \\
\hline $\begin{array}{l}\text { Ptosis } \\
\text { Congenital glaucoma }\end{array}$ & + & & + & & & & \\
\hline Epicanthic folds & & & + & & & + & + \\
\hline Synophrys & & + & + & & & & + \\
\hline Strabismus & & + & + & & + & & + \\
\hline \multicolumn{8}{|l|}{ Ears } \\
\hline Large, protuberant & & + & + & & & + & + \\
\hline Folded over helix & & + & + & & & & \\
\hline Poor helix formation & & & & + & & & + \\
\hline $\begin{array}{l}\text { Preauricular skin tags } \\
\text { Low set, malformed }\end{array}$ & & & & & + & & + \\
\hline \multicolumn{8}{|l|}{ Nose } \\
\hline Short, bulbous & & + & + & & & & + \\
\hline Depressed nasal bridge & & + & + & & & & + \\
\hline Broad nasal bridge & & & & + & & & + \\
\hline \multicolumn{8}{|l|}{ Mouth } \\
\hline Cleft lip and palate & + & & & & & & \\
\hline $\begin{array}{l}\text { Micrognathia } \\
\text { High arched/narrow }\end{array}$ & & & + & + & + & + & + \\
\hline $\begin{array}{l}\text { High arched/narrow } \\
\text { palate }\end{array}$ & & & & + & + & + & + \\
\hline Pointed chin & & + & & & & + & \\
\hline Broad philtrum & & & & + & & + & + \\
\hline \multicolumn{8}{|l|}{ Orthopaedic } \\
\hline \multicolumn{8}{|l|}{ Leg and foot } \\
\hline Arm and hand & & & & & & & \\
\hline abnormalities & & + & + & & + & & + \\
\hline Hip luxation & & & & & + & & + \\
\hline Scoliosis & & + & & & & + & + \\
\hline \multicolumn{8}{|l|}{ Other } \\
\hline $\begin{array}{l}\text { Congenital heart disease } \\
\text { Genitourinary }\end{array}$ & & + & + & + & & & + \\
\hline abnormality & & + & + & & & & + \\
\hline Seizures & & + & & & + & & + \\
\hline Mental retardation & & + & + & & + & + & + \\
\hline
\end{tabular}

techniques from peripheral leucocyte cultures (fig 3). Chromosome studies on her parents showed normal karyotypes.

\section{Discussion}

Common findings in $r(14)$ syndrome are noted in the table. There have been five cases of $14 q-$ reported. ${ }^{1-4}$ These are summarised in the table including findings in the case reported. Although some common features are reported, at present they are not consistent enough to establish a clinical entity. Some of the features seen in $14 q-$ are seen in $r(14)$, where deletions in both the short and the long arms of chromosome 14 have been reported.

This study was supported in part by a grant from the Division for Maternal and Child Health Services, Department for Health Services, Cabinet for Human Resources, Commonwealth of Kentucky, USA.

\section{References}

${ }^{1}$ Buchanan P, Rao K, Doerr C, Aylsworth A. A complex translocation involving chromosomes 3,11 , and 14 with an interstitial deletion, del(14)(q13q22) in a child with congenital glaucoma and cleft lip and palate. Birth Defects 1978;XIV (6c):317-22.

2 Turleau C, de Grouchy J, Chavin-Colin F, et al. Two patients with interstitial del(14q), one with features of Holt-Oram syndrome. Exclusion mapping of PI (alpha-1-antitrypsin). Ann Genet (Paris) 1984;27:237-40.

${ }^{3}$ Hreidarsson S, Stamberg J. Distal monosomy 14 not associated with ring formation. J Med Genet 1983;20:147-9.

${ }^{4}$ Nielsen J, Homma A, Rasmussen K, Ried E, Sorensen K, Saldana-Garcia P. Deletion $14 \mathrm{q}$ and pericentric inversion $14 . J$ Med Genet 1978;15:236-8.

5 Schmidt R, Eviatar L, Nitowsky HM, Wong M, Miranda S. Ring chromosome 14: a distinct clinical entity. $J$ Med Genet 1981;18:304-7.

Correspondence and requests for reprints to Dr F-S Yen, Child Evaluation Center, Department of Pediatrics, University of Louisville School of Medicine, 334 East Broadway, Louisville, Kentucky 40202, USA.

\title{
Familial distal trisomy $8(\mathrm{q} 24.13 \rightarrow \mathrm{qter})$
}

\author{
D R ROMAIN*, R A BLOXHAM†, L M COLUMBANO-GREEN* \\ C J CHAPMAN*, R G PARFITT*, R H SMYTHE*, AND H CAIRNEY* \\ ${ }^{*}$ Cytogenetics Laboratory, Department of Laboratory Services, Wellington Hospital, Wellington; and \\ †Department of Paediatrics, Palmerston North Hospital, Palmerston North, New Zealand.
}

SUMMARY Trisomy for the distal part of the long arm of chromosome $8(\mathrm{q} 24.13 \rightarrow \mathrm{qter})$ is

Received for publication 6 April 1988.

Revised version accepted for publication 8 June 1988 described in three sibs. The anomaly arose as an adjacent 1 meiotic segregation from a balanced reciprocal translocation $\mathrm{t}(1 ; 8)(\mathrm{q} 44$; q24.13)mat. 